\title{
Sporomusa aerivorans sp. nov., an oxygen- reducing homoacetogenic bacterium from the gut of a soil-feeding termite
}

\author{
Hamadi I. Boga, ${ }^{1} \dagger$ Wolfgang Ludwig ${ }^{2}$ and Andreas Brune ${ }^{1}$ \\ ${ }^{1}$ Lehrstuhl für Mikrobielle Ökologie, Fachbereich Biologie, Universität Konstanz, Fach M 654, \\ 78457 Konstanz, Germany \\ ${ }^{2}$ Lehrstuhl für Mikrobiologie, Technische Universität München, Am Hochanger 4, 85350 \\ Freising, Germany
}

Andreas Brune

Andreas.Brune@uni-konstanz.de

\begin{abstract}
Previously undescribed, homoacetogenic bacteria were isolated from gut homogenates of the soil-feeding termite Thoracotermes macrothorax. The isolates were slightly curved, banana-shaped rods $(0 \cdot 6-0 \cdot 7 \times 1 \cdot 3-7 \cdot 0 \mu \mathrm{m})$ and were motile by one or more lateral flagella. In older cultures, cells formed club-like sporangia that developed into terminal, heat-resistant endospores. Cells stained Gram-positive but were Gram-negative in the $\mathrm{KOH}$ test. The isolates were mesophilic and grew homoacetogenically on $\mathrm{H}_{2} / \mathrm{CO}_{2}$ and L-lactate. Strain $\mathrm{TmAO}^{\top}$, which was characterized further, also grew homoacetogenically on pyruvate, citrate, L-alanine, D-mannitol, ethanol, formate and methanol. Succinate was decarboxylated to propionate; fumarate, L-malate and oxaloacetate were fermented to propionate and acetate. Hexoses were not used as substrates. Resting cells had a large capacity for hydrogen-dependent oxygen reduction [826 nmol min (mg protein $)^{-1}$ ], which enabled them to initiate growth in non-reduced basal medium that originally contained up to $1.5 \mathrm{kPa}$ oxygen in the headspace, although growth commenced only after the medium had been rendered anoxic. Redox difference spectra of cell extracts indicated the presence of membrane-bound $b$-type cytochrome(s). Comparative 16S rRNA gene sequence analysis revealed that strain $\mathrm{TmAO}^{\top}$ belongs to a subgroup of the phylum of Gram-positive bacteria that is characterized by low DNA G $+\mathrm{C}$ content and a Gram-negative cell wall. It is related most closely to representatives of the genus Sporomusa. Based on morphological and physiological properties and on 16S rRNA gene sequence similarity of 94-97\% to other Sporomusa species, the isolates are assigned to Sporomusa aerivorans sp. nov. (type strain, $\mathrm{TmAO}^{\top}=\mathrm{DSM} 13326^{\top}$ $=$ ATCC BAA $-625^{\top}$ ).
\end{abstract}

Reductive acetogenesis from $\mathrm{H}_{2}$ and $\mathrm{CO}_{2}$ in gut homogenates of wood-feeding termites was first reported by Breznak \& Switzer (1986). In the following years, the presence of homoacetogenic activity has been demonstrated for a large number of termite species from all major feeding guilds, including representatives of wood-feeding, funguscultivating and soil-feeding termites (Brauman et al., 1992). Although reductive acetogenesis was always out-competed as a hydrogen sink by methanogenesis in gut homogenates of soil-feeding termites (Brauman et al., 1992), microinjection of $\mathrm{H}^{14} \mathrm{CO}_{3}^{-}$into intact hindguts of soil-feeding

Published online ahead of print on 7 February 2003 as DOI 10.1099/ ijs.0.02534-0.

tPresent address: Botany Department, Jomo Kenyatta University of Agriculture and Technology, PO Box 62000, Nairobi, Kenya.

The GenBank/EMBL/DDBJ accession numbers for the 16S rRNA gene sequences of strains $\operatorname{TmAO}^{\top}$ and $\operatorname{TmAM} 3$ are AJ506191 and AJ506192, respectively.
Cubitermes spp. has identified a high potential for reductive acetogenesis (Tholen \& Brune, 1999), indicating that the contribution of reductive acetogenesis to overall electron flow in the guts of soil-feeding termites may be larger than expected.

In order to define the metabolic potential of termite gut homoacetogens and to identify specific adaptations to the gut environment, it is necessary to study these bacteria in pure culture (Brune et al., 2000). However, only five strains of homoacetogenic bacterium have so far been isolated from termite guts, four of them from wood-feeding species. They comprise Sporomusa termitida and Acetonema longum from Nasutitermes nigriceps and Pterotermes occidentis (Breznak et al., 1988; Kane \& Breznak, 1991) and two spirochaetal isolates, strains ZAS-1 and ZAS-2, from Zootermopsis angusticollis (Leadbetter et al., 1999). Only one homoacetogenic bacterium, Clostridium mayombei (Kane et al., 1991), has been obtained from a soil-feeding termite (Cubitermes 
speciosus). Nevertheless, each of these isolates was a member of a novel genus or species affiliated with a different phylogenetic group and it is reasonable to assume that they represent only a negligible fraction of the diversity of homoacetogens that colonize the guts of more than 2600 known species of termite (Kambhampati \& Eggleton, 2000).

Clearly, more isolates are needed to understand the physiological role and ecological significance of homoacetogenic bacteria in termite guts. In this study, we describe the isolation and characterization of a novel homoacetogenic bacterium from the gut of the soil-feeding termite Thoracotermes macrothorax. Further physiological characterization of this strain, which is the subject of a separate study (Boga \& Brune, 2003), led to the surprising discovery of high oxygen-reducing capacity in this and other homoacetogenic bacteria isolated from termite guts.

\section{Isolation and morphological characterization}

Gut homogenates were prepared from different gut sections of the termite Thoracotermes macrothorax Sjöstedt (Tholen \& Brune, 1999) and diluted serially in anoxic, bicarbonatebuffered mineral medium (AM-5) supplemented with yeast extract and Casamino acids (each $0 \cdot 1 \%$, w/v) (Boga \& Brune, 2003). Enrichment cultures with lactate $(8 \mathrm{mM})$ as an additional substrate and DTT $(1 \mathrm{mM})$ as a reducing agent were incubated in an $\mathrm{H}_{2} / \mathrm{CO}_{2}$ atmosphere $(80: 20, \mathrm{v} / \mathrm{v}$; $150 \mathrm{kPa}$ ). The highest dilutions where net acetate production indicated the presence of reductive acetogenesis were transferred into fresh medium. Subsequent agar dilution series (Pfennig \& Trüper, 1981), conducted in the same medium but incubated in an $\mathrm{N}_{2} / \mathrm{CO}_{2}$ atmosphere, yielded mostly light-brown, lentil-shaped colonies from which several pure cultures were obtained.
Phase-contrast microscopy revealed morphologically indistinguishable, curved rods with slightly tapered ends, which resembled the shape of a banana. Strain TmAM3, which was derived from a homogenate of midgut and mixed segment, and strain $\mathrm{TmAO}^{\mathrm{T}}$, which stemmed from a homogenate that comprised the third and fourth proctodeal segment, were selected for further characterization. In each case, the dilution steps indicated an original population of approximately $10^{3}-10^{4}$ cells per gut section.

Both strains stained Gram-positive but reacted Gramnegative in the $\mathrm{KOH}$ test (Gregersen, 1978); Bacillus megaterium (DSM 32 ${ }^{\mathrm{T}}$ ) and Escherichia coli (DSM 498) were used as controls. Cells of strain $\mathrm{TmAO} 3^{\mathrm{T}}$ were $3-7 \mu \mathrm{m}$ long and $0 \cdot 6-0 \cdot 7 \mu \mathrm{m}$ wide and occurred singly or in pairs (Fig. 1a). In the stationary growth-phase, they formed terminal endospores in club-shaped sporangia that tended to aggregate in a characteristic manner (Fig. 1b). Older cultures sporulated completely and remained viable when pasteurized $\left(80^{\circ} \mathrm{C}, 10 \mathrm{~min}\right)$. Cells were motile by means of one or more lateral flagella (Figs $1 \mathrm{c}$ and d). Identical results were obtained with strain TmAM3.

\section{Growth and nutrition}

Cultures were grown routinely at $30^{\circ} \mathrm{C}$ and $\mathrm{pH}$ 7. Growth was determined photometrically by following increase in $\mathrm{OD}_{578}$. Growth yields were estimated by using an OD-tocell-mass conversion factor that was determined with cultures (1 l) grown on lactate in $\mathrm{N}_{2} / \mathrm{CO}_{2}$. Substrate utilization and product formation were assayed by HPLC with an ionexclusion column and a refractive index detector (Tholen et al., 1997). Aromatic acids were quantified by reversedphase HPLC as described previously (Brune \& Schink, 1990).
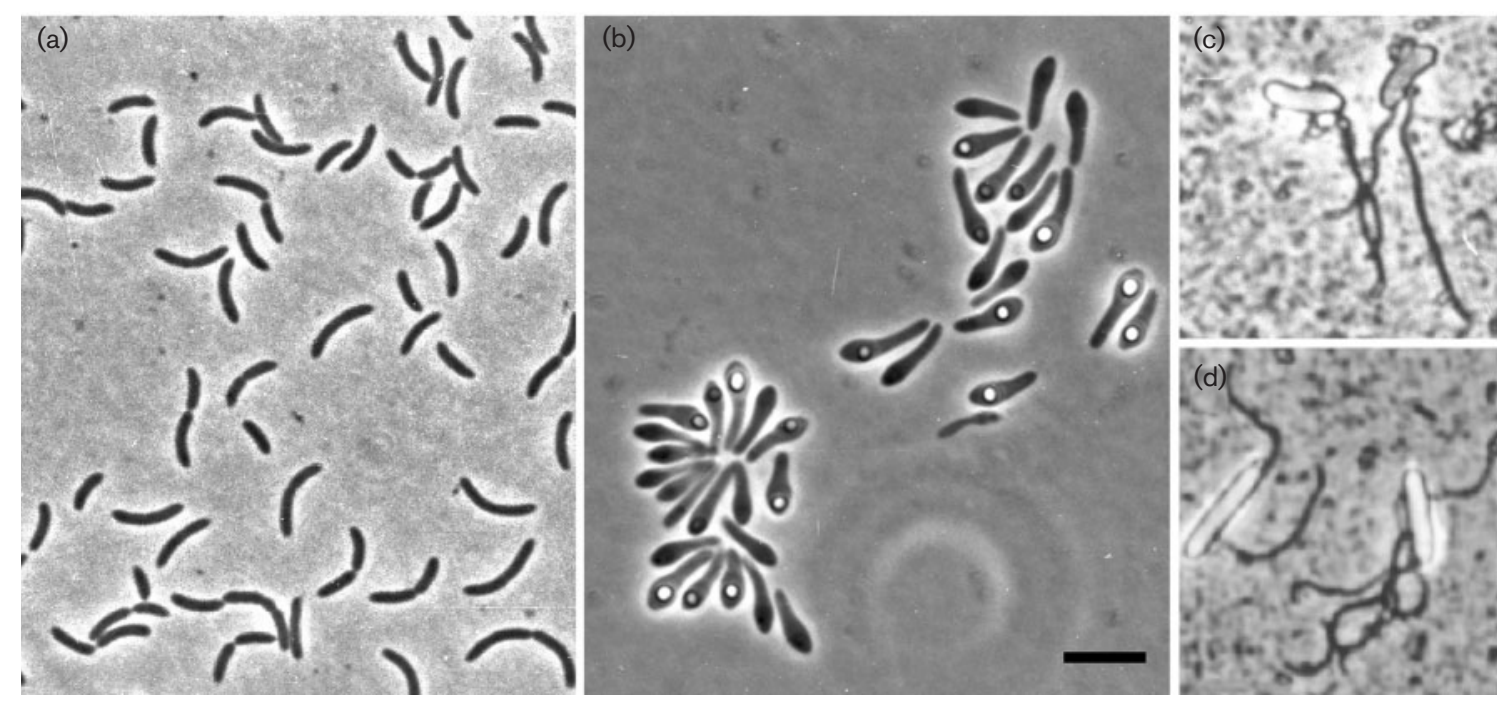

Fig. 1. Phase-contrast photomicrographs of cells from a growing culture of strain $\operatorname{TmAO} 3^{\top}$ (a), during sporulation (b) and after a flagella stain (c, d). Wet mounts for microphotography (Pfennig \& Wagener, 1986) and flagella stains (Blenden \& Goldberg, 1965) were prepared as described. Bar, $5 \mu \mathrm{m}$. 
Both strains required an oxygen-free, reduced medium for growth. They grew best in medium reduced with DTT $(1 \mathrm{mM})$ or cysteine $(2 \mathrm{mM})$. Good growth was also obtained when a palladium catalyst was added to reduce medium incubated in an $\mathrm{H}_{2} / \mathrm{CO}_{2}$ atmosphere (Tholen et al., 1997). The strains grew homoacetogenically on $\mathrm{H}_{2} / \mathrm{CO}_{2}$ or L-lactate but required small amounts $(0 \cdot 1 \%, \mathrm{w} / \mathrm{v})$ of yeast extract or Casamino acids, which were fermented to acetate and traces of propionate. As the results of all initial growth tests were identical for both isolates, only strain $\mathrm{TmAO}^{\mathrm{T}}$ was characterized in more detail.

On basal medium with lactate, cells grew at $\mathrm{pH} 6 \cdot 2-8 \cdot 2[\mathrm{pH}$ adjusted by adding sterile $\mathrm{Na}_{2} \mathrm{CO}_{3}(1 \mathrm{M})$ or $\left.\mathrm{HCl}(1 \mathrm{M})\right]$ and at $19-35^{\circ} \mathrm{C}$, but not at 4 or $40^{\circ} \mathrm{C}$. Highest growth yields were obtained at $30^{\circ} \mathrm{C}$ and $\mathrm{pH} 7$. Under these conditions, cultures reached similar densities on $\mathrm{H}_{2} / \mathrm{CO}_{2} \quad(80: 20$; $150 \mathrm{kPa}$ ) or lactate $(8.1 \mathrm{mM})$ (Fig. 2), but the respective growth yields differed considerably $[2 \cdot 5$ and $6 \cdot 0 \mathrm{~g}$ dry wt (mol acetate) $)^{-1}$, corrected for background growth and acetate production on basal medium]. Doubling times of cultures growing on $\mathrm{H}_{2} / \mathrm{CO}_{2}$ or lactate were 8.9 and $4.4 \mathrm{~h}$, respectively. In cultures growing on $\mathrm{H}_{2} / \mathrm{CO}_{2}$, growth was exponential only at lower cell densities. Most likely, mass transfer of $\mathrm{H}_{2}$ from the gas phase into the liquid medium became limiting as cell density increased.

Strain $\mathrm{TmAO3}^{\mathrm{T}}$ also grew on alanine, citrate, mannitol, formate, pyruvate, ethanol and methanol. In all cases, acetate was the only product detected by HPLC analysis.

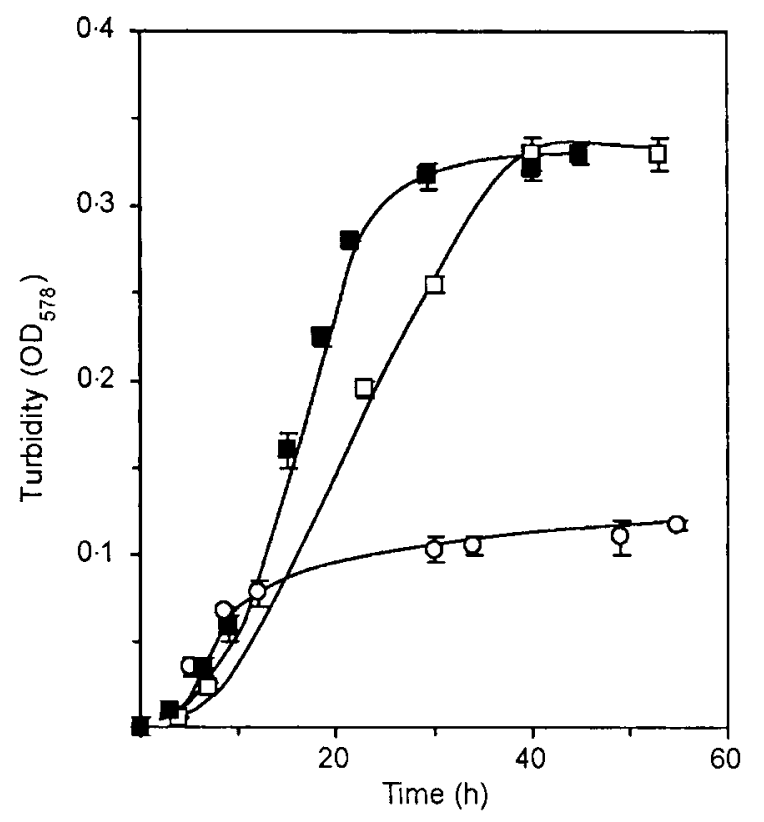

Fig. 2. Growth of strain $\mathrm{TmAO}^{\top}$ on lactate $(8 \cdot 1 \mathrm{mM})(\boldsymbol{\square})$ or $\mathrm{H}_{2} / \mathrm{CO}_{2}(80: 20 ; 150 \mathrm{kPa})(\square)$ in basal medium that contained yeast extract and Casamino acids (each $0 \cdot 1 \%$, w/v). Background growth on basal medium alone $(\bigcirc)$. Values are means of two cultures.
Substrate-free controls showed that growth and acetate production on basal medium were substantial. Nevertheless, the product pattern and electron recovery obtained with L-lactate, L-alanine and D-mannitol were close to the theoretical values expected for a purely homoacetogenic metabolism (Table 1), i.e. all reducing equivalents from substrate oxidation to acetate were apparently used for further (reductive) acetogenesis from $\mathrm{CO}_{2}$.

In contrast, dicarboxylic acids such as L-malate, fumarate and oxaloacetate were fermented to varying amounts of propionate and acetate; consistently incomplete utilization of the racemic mixture of DL-malate indicates that D-malate was not used. Propionate was virtually the only product formed from succinate and the growth-yield increase in the presence of succinate indicates that strain $\mathrm{TmAO}^{\mathrm{T}}$ derives energy from succinate decarboxylation, most likely via the methylmalonyl-CoA pathway. However, no increased growth yield was associated with the decarboxylation of malonate to acetate (Table 1).

Strain $\mathrm{TmAO}^{\mathrm{T}}$ also grew by demethylation of vanillate, syringate and 3,4,5-trimethoxybenzoate (each $2 \mathrm{mM}$ ), forming acetate and the corresponding phenolates (protocatechuate or gallate) as demethylation products. No growth occurred with glucose, fructose, lactose, cellobiose, trehalose or ethylene glycol (5 or $10 \mathrm{mM}$ each) or with glycerol, oxalate, glyoxylate, aspartate or glutamate (10 or $20 \mathrm{mM}$ each). Sulfate and nitrate $(10 \mathrm{mM}$ each) were not reduced (this was tested with lactate as electron donor).

\section{Cytochrome content}

Cultures were centrifuged at $10000 \mathrm{~g}$ for $30 \mathrm{~min}$ and cells were washed and then resuspended in anoxic buffer. Cell extracts were prepared by repeatedly passing the cell suspension through a French pressure cell at $138 \mathrm{MPa}$. Crude extract was centrifuged again $(30000 \mathrm{~g}, 20 \mathrm{~min})$ and the supernatant (cell-free extract) was fractionated into a membrane fraction and a soluble fraction by ultracentrifugation $(126000 \mathrm{~g}, 1 \mathrm{~h})$. Fractions were assayed for the presence of cytochromes by recording difference spectra of $\mathrm{N}_{2} \mathrm{~S}_{2} \mathrm{O}_{4}{ }^{-}$ reduced minus air-oxidized samples, as described previously (Breznak et al., 1988). All procedures were carried out in potassium phosphate buffer $(0 \cdot 1 \mathrm{M}, \mathrm{pH} 7)$.

Redox difference spectra of cell extracts from lactate-grown (Fig. 3) and hydrogen-grown (not shown) cells of strain $\mathrm{TmAO}^{\mathrm{T}}$ showed absorption maxima at 562, 545 and $432 \mathrm{~nm}$, which are characteristic of $b$-type cytochrome(s) (Dickerson \& Timkovich, 1975). Absence of other absorption maxima and the fact that maxima were found only in the spectra of the membrane fraction after ultracentrifugation indicated that $a$ - or $c$-type cytochromes were not present.

\section{Phylogenetic analysis}

$16 \mathrm{~S}$ rRNA genes were amplified in vitro by PCR and the sequences were analysed as described previously (Springer et al., 1992). The 16S rRNA gene sequences (homologous to 
Table 1. Growth yields and fermentation products of strain $\operatorname{TmAO} 3^{\top}$ grown on selected substrates in an $\mathrm{N}_{2} / \mathrm{CO}_{2}$ atmosphere

Background growth and product formation on basal medium were subtracted for the calculation of electron recoveries and substrate-specific growth yields. As cells were grown in bicarbonate-buffered medium, $\mathrm{CO}_{2}$ formation could not be analysed. Values are means of two replicates $(<5 \%$ variance). ND, Not determined.

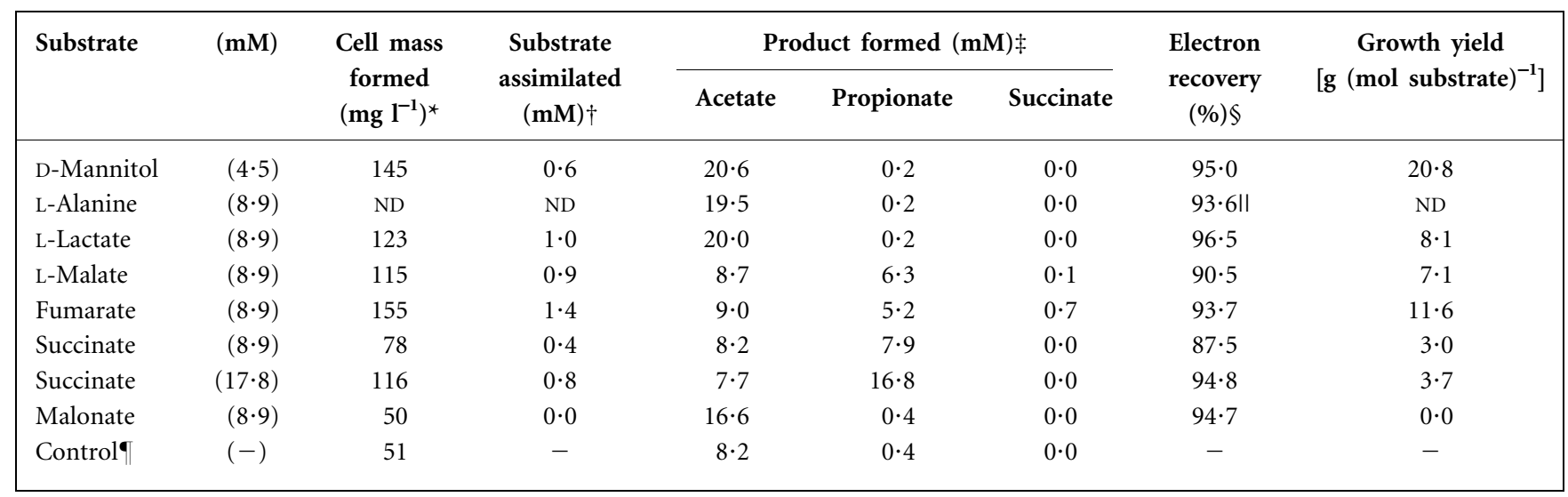

${ }^{\star}$ Calculated from increase in optical density by using the OD-to-dry-mass ratio of $343 \mathrm{mg} 1^{-1}$ at $\mathrm{OD}_{578}=1$, experimentally determined for lactate-grown cells of strain $\mathrm{TmAO}^{\mathrm{T}}$.

$\dagger$ Assimilated substrate was calculated as the amount of substrate necessary for formation of the indicated amount of cell mass, observing a closed oxidation-reduction balance and assuming a cell composition of ' $\mathrm{C}_{4} \mathrm{H}_{7} \mathrm{O}_{3}$ '.

$\ddagger$ Values are not corrected for background growth and product formation on basal medium.

$\$$ Calculated after subtracting the amount of substrate assimilated and the electrons contained in the products also formed in the control.

IIElectron recovery calculated by using assimilated substrate of culture growing on lactate.

- Substrate-free controls contained yeast extract and Casamino acids $(0 \cdot 1 \%$ each, w/v).

E. coli positions 8-1542) of the isolates were fitted into an alignment of about 40000 homologous full or partial primary structures that are available in public databases

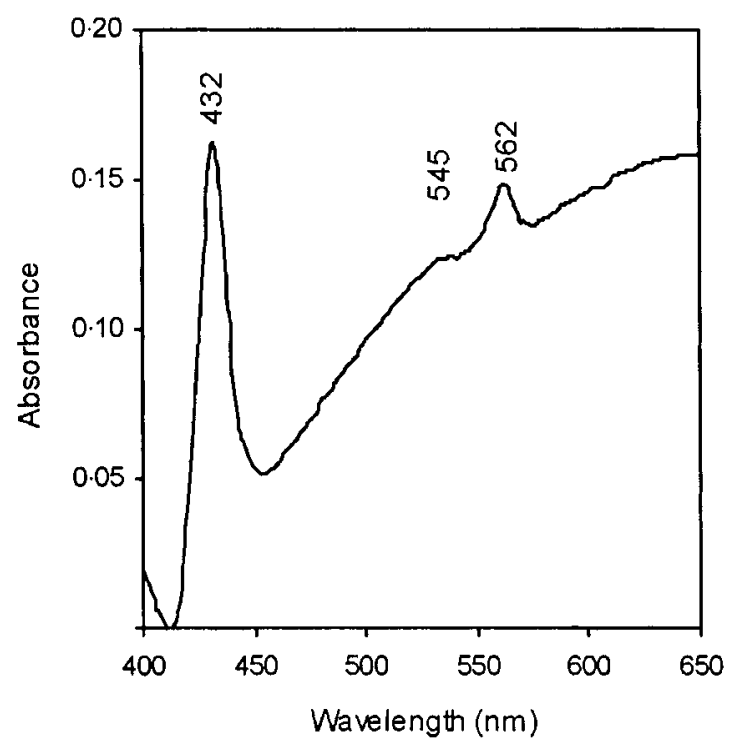

Fig. 3. Redox difference spectrum of the membrane fraction of strain $\mathrm{TmAO}^{\top}$ grown on lactate, showing absorption maxima that indicate the presence of a $b$-type cytochrome. No absorption maxima were detected in the soluble fraction. The assay contained $5 \mathrm{mg}$ protein $\mathrm{ml}^{-1}$.
(Ludwig, 1995) by using the automated tools of the ARB software package (Ludwig \& Strunk, 1996). Distance-matrix, maximum-parsimony and maximum-likelihood methods were applied for tree construction, as implemented in the ARB software package. Different datasets, which varied with respect to the selection of outgroup reference organisms as well as alignment positions, were analysed.

The almost-complete 16S rRNA gene sequences obtained for strains $\mathrm{TmAO}^{\mathrm{T}}$ and TmAM3 were nearly identical (>99.5\% sequence similarity). Comparative sequence analysis revealed that both strains were phylogenetically most closely related to members of the genus Sporomusa (Fig. 4), which belongs to a subgroup of Gram-positive bacteria with a low DNA G $+\mathrm{C}$ content that is characterized by organisms with a Gram-negative cell wall (Willems \& Collins, 1995). All phylogenetic analyses placed the sequences of strains $\mathrm{TmAO}^{\mathrm{T}}$ and TmAM3 at the base of the Sporomusa species cluster; sequence similarity to other members of the genus Sporomusa ranged from 94 to $97 \%$. Highest values were obtained with Sporomusa sphaeroides (96.8\%) and Sporomusa sp. strain DR5 (97.0\%), which was isolated from anoxic bulk soil of flooded rice microcosms (Rosencrantz et al., 1999). Sequence similarity to representatives of other genera in the subgroup was $<91 \cdot 6 \%$.

\section{Taxonomy}

The physiological characteristics of strain $\mathrm{TmAO}^{\mathrm{T}}$ clearly identify it as a homoacetogenic bacterium. Like most other 


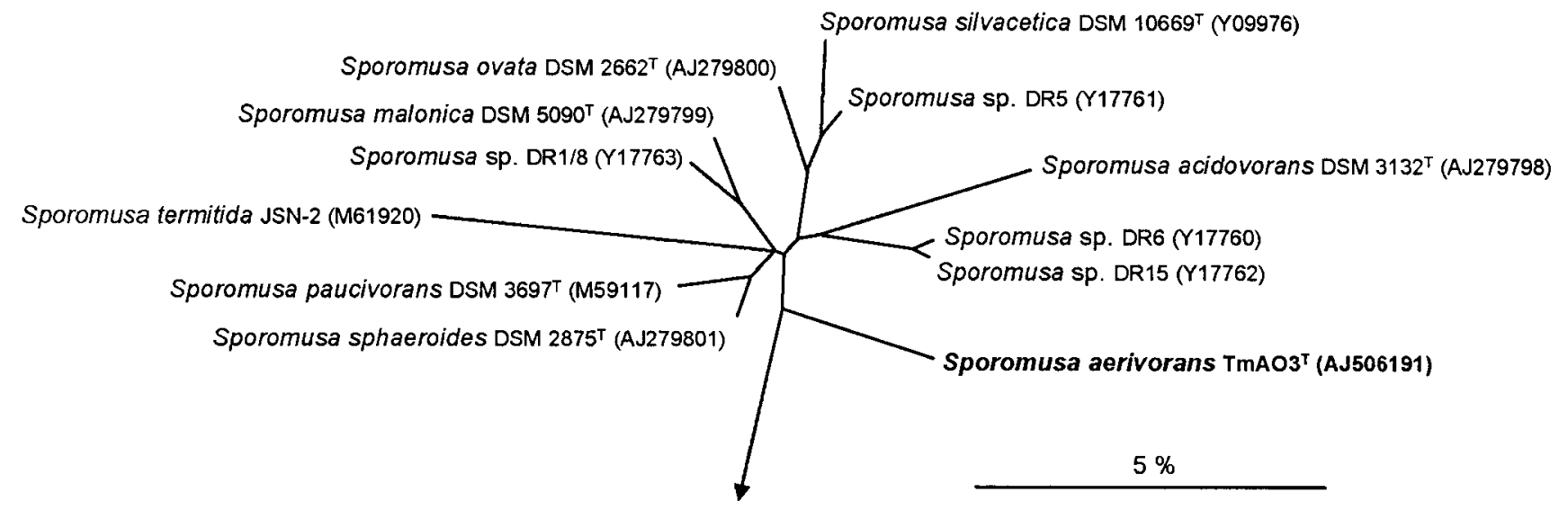

Fig. 4. Phylogenetic relationship of Sporomusa aerivorans (strain $T m A O 3^{\top}$ ) and other species in the genus Sporomusa. The tree is based on maximum-likelihood analysis of the 16S rRNA gene sequences of these strains and a selection of 100 reference organisms, including the closely related genera Acidaminococcus, Anaeromusa, Dendrosporobacter, Desulfotomaculum, Dialister, Megasphaera, Pectinatus, Phascolarctobacterium, Quinella, Schwartzia, Selenomonas, Succiniclasticum, Succinispira, Veillonella and Zymophilus and other Gram-positive bacteria with a low DNA G+C content, which also served to define the root of the tree. Only alignment positions that were invariant among at least $50 \%$ of these sequences were included in the calculations. The tree topology was evaluated and corrected according to the results of distance matrix and maximum-parsimony analyses. Multifurcations indicate that a significant relative branching order could not be determined unambiguously or was not supported by the results of the alternative treeing procedures. GenBank/EMBL accession numbers of the sequences are given in parentheses. Bar, $5 \%$ estimated sequence divergence.

bacteria in this physiological group, it catalyses the $\mathrm{H}_{2}$-dependent reduction of $\mathrm{CO}_{2}$ to acetate and ferments lactate, ethanol and other substrates homoacetogenically, i.e. all reducing equivalents from substrate oxidation to acetate are used for further (reductive) acetogenesis from $\mathrm{CO}_{2}$. The presence of $\mathrm{CO}$ dehydrogenase $[11 \cdot 5 \mu \mathrm{mol} \mathrm{CO}$ oxidized $\min ^{-1}\left(\mathrm{mg}\right.$ protein $\left.\left.{ }^{-1}\right)\right]$ has been demonstrated (Boga \& Brune, 2003). Also, the demethylation of O-methyl ethers and subsequent fermentation of the methyl groups to acetate and the utilization of other $\mathrm{C}_{1}$ compounds such as formate and methanol are typical of many homoacetogens (see reviews by Diekert, 1992; Drake et al., 1994; Schink, 1994).

$16 \mathrm{~S}$ rRNA gene sequence analysis revealed that strains $\mathrm{TmAO}^{\mathrm{T}}$ and TmAM3 are most closely related to members of the genus Sporomusa. Their phenotypic characteristics are also typical of members of this genus (Möller et al., 1984): cells are curved, banana-shaped rods, form heat-resistant endospores, are motile by one or more lateral flagella, possess $b$-type cytochromes and form acetate as the major fermentation product.

In its substrate utilization spectrum, strain $\mathrm{TmAO}^{\mathrm{T}}$ most closely resembles $S$. termitida, a homoacetogenic isolate from a wood-feeding termite (Breznak et al., 1988), which was included in this study as a reference strain. Both strains can be clearly differentiated from other members of the genus Sporomusa by their inability to grow on fructose and glycerol and their ability to grow on mannitol, citrate and succinate (Table 2). However, the strains differ significantly in their 16S rRNA gene sequence (94\% similarity) and the ability to ferment dicarboxylic acids. Strain $\mathrm{TmAO}^{\mathrm{T}}$ grows on L-malate and fumarate, whereas cells of $S$. termitida do not grow on these substrates (Table 2). Cells of strain $\mathrm{TmAO}^{\mathrm{T}}$ are also curved more strongly and, in contrast to S. termitida, are not sensitive to reducing agents such as DTT and cysteine (Breznak et al., 1988; this study).

\section{Physiology and ecology}

Like most homoacetogens (Schink, 1994; Drake et al., 1997), strain $\mathrm{TmAO} 3^{\mathrm{T}}$ is metabolically quite versatile. It ferments a large number of organic substrates homoacetogenically, utilizing reductive acetogenesis from $\mathrm{CO}_{2}$ as an acceptor for the electrons released during substrate oxidation to acetate. The inability to ferment glucose or other sugars is unusual but encountered frequently among Sporomusa species (Table 2). Also, fermentation of dicarboxylic acids, e.g. fumarate and L-malate, is not a common trait among homoacetogens, but again, it is not uncommon in the genus Sporomusa (Table 2). It has been suggested that $b$-type cytochromes, which are present in many Sporomusa species (including strain $\mathrm{TmAO3}^{\mathrm{T}}$ ), are involved in fumarate reduction (Diekert, 1992; Diekert \& Wohlfarth, 1994). However, $b$-type cytochromes are also present in species that do not grow on dicarboxylic acids (S. termitida, Sporomusa ovata and $S$. sphaeroides) and there is evidence for $S$. sphaeroides that $b$-type cytochromes are also involved in the oxidation of methyl groups (Kamlage \& Blaut, 1993).

Molecular hydrogen is a typical product that is formed by 
Table 2. Selected morphological and physiological properties that differentiate strain $\operatorname{TmAO}^{\top}$ from other members of the genus Sporomusa

Species: 1, strain $\operatorname{TmAO}^{\mathrm{T}}$; 2, S. termitida; 3, S. ovata; 4, S. sphaeroides; 5, Sporomusa acidovorans; 6, Sporomusa paucivorans; 7, Sporomusa malonica; 8, S. silvacetica. +, Positive; -, negative; W, weakly positive; \pm , most strains positive; ND, not determined.

\begin{tabular}{|c|c|c|c|c|c|c|c|c|}
\hline Property & 1 & 2 & 3 & 4 & 5 & 6 & 7 & 8 \\
\hline Width $(\mu \mathrm{m})$ & $0 \cdot 6-0 \cdot 7$ & $0 \cdot 5-0 \cdot 8$ & $0 \cdot 9-1$ & $0 \cdot 5-0 \cdot 9$ & $0 \cdot 7-1$ & $0 \cdot 4-0 \cdot 7$ & $0 \cdot 7$ & $0 \cdot 7$ \\
\hline Length $(\mu \mathrm{m})$ & $1 \cdot 3-7$ & $2-8$ & $1 \cdot 3-1 \cdot 4$ & $2-5$ & $2-8$ & $2-3$ & $2 \cdot 6-4 \cdot 8$ & 3 \\
\hline Formation of endospores & + & + & + & + & + & - & + & + \\
\hline Catalase activity & + & + & $\mathrm{W}$ & + & ND & - & - & - \\
\hline \multicolumn{9}{|l|}{ Utilization of: } \\
\hline Fructose & - & - & \pm & - & + & - & + & + \\
\hline Mannitol & + & + & - & - & ND & - & $\mathrm{ND}$ & - \\
\hline Glycerol & - & - & - & + & + & + & - & + \\
\hline Citrate & + & + & - & - & - & - & + & - \\
\hline L-Malate & + & - & - & - & + & - & + & ND \\
\hline Fumarate & + & - & - & - & + & - & + & + \\
\hline Succinate & + & + & - & - & $+^{*}$ & - & + & - \\
\hline Source of type strain & Termite gut & Termite gut & Silage & $\begin{array}{l}\text { River } \\
\text { sediment }\end{array}$ & $\begin{array}{l}\text { Distillery } \\
\text { waste water }\end{array}$ & $\begin{array}{l}\text { Lake } \\
\text { sediment }\end{array}$ & $\begin{array}{c}\text { Freshwater } \\
\text { sediment }\end{array}$ & Forest soil \\
\hline Reference & This study & $\begin{array}{l}\text { Breznak } \\
\text { et al., } 1988\end{array}$ & $\begin{array}{l}\text { Möller } \\
\text { et al., } 1984\end{array}$ & $\begin{array}{l}\text { Möller } \\
\text { et al., } 1984\end{array}$ & $\begin{array}{l}\text { Ollivier } \\
\text { et al., } 1985\end{array}$ & $\begin{array}{l}\text { Hermann } \\
\text { et al., } 1987\end{array}$ & $\begin{array}{l}\text { Dehning } \\
\text { et al., } 1989\end{array}$ & $\begin{array}{l}\text { Kuhner et al., } \\
\text { 1997; Karnholz } \\
\text { et al., } 2002\end{array}$ \\
\hline
\end{tabular}

*Produces acetate from succinate (Ollivier et al., 1985), whereas the other species form propionate as the major product.

fermentative degradation of organic compounds (Schink, 1997) and hydrogen-consuming processes, such as reductive acetogenesis and methanogenesis, seem to be important electron sinks in the hindguts of all termites studied so far (Brauman et al., 1992; Schmitt-Wagner \& Brune, 1999; Tholen \& Brune, 1999). In soil-feeding Termitinae, methanogenesis seems to dominate over reductive acetogenesis as a hydrogen sink, possibly due to the lower affinity of homoacetogens for $\mathrm{H}_{2}$ (Breznak, 1994). Nevertheless, the presence of high potential rates of reductive acetogenesis in soil-feeding termites indicates that they are able to coexist with other hydrogenotrophic populations (Tholen \& Brune, 1999).

It is possible that the metabolic versatility of homoacetogenic bacteria allows them to maintain an active metabolism during phases of low $\mathrm{H}_{2}$ partial pressure in the gut (Tholen \& Brune, 1999). Hindgut fluid of soil-feeding termites contains considerable concentrations of potential substrates for homoacetogens, e.g. lactate and ethanol (E. Miambi, H. I. Boga, A. Tholen \& A. Brune, unpublished data), and probably also methoxylated aromatic compounds that are derived from lignins or humic acids. Recent findings indicate that peptides and amino acids may also be important substrates for the gut microbiota of soil-feeding termites (Ji et al., 2000). Mixotrophy, i.e. the ability of homoacetogens to use $\mathrm{H}_{2}$ and organic substrates simultaneously, as observed for S. termitida (Breznak \& Blum, 1991), would add to their competitiveness (Breznak, 1994).

Strain $\mathrm{TmAO}^{\mathrm{T}}$ was isolated from a dilution step that indicated a population of approximately $10^{3}-10^{4}$ cells per gut section, which is in good agreement with the estimated total number of homoacetogens growing in serial dilutions of gut homogenates of Thoracotermes macrothorax (E. Miambi, H. I. Boga, A. Tholen \& A. Brune, unpublished data). Nevertheless, the large discrepancy between viable counts and total cell counts, together with the high potential rates of reductive acetogenesis in the guts of soil-feeding termites, indicate a strong cultivation bias against homoacetogens (Tholen \& Brune, 1999).

\section{Oxygen reduction}

Drake and coworkers were the first to document tolerance and metabolic response to the presence of oxygen for a number of homoacetogens, including Sporomusa silvacetica (Küsel et al., 2001; Karnholz et al., 2002). In an independent study, we have shown that strain $\mathrm{TmAO}^{\mathrm{T}}$ and other strains of homoacetogen isolated from termite guts consume oxygen at high rates (Boga \& Brune, 2003).

Strain $\mathrm{TmAO}^{\mathrm{T}}$ has by far the highest capacity for hydrogen-dependent oxygen reduction $\left[826 \mathrm{nmol} \mathrm{\textrm {min } ^ { - 1 }}\right.$ $(\mathrm{mg} \text { protein })^{-1}$ ] of all homoacetogens tested (Boga \& Brune, 2003); it is surpassed only by that reported for several Desulfovibrio species isolated from termite guts (Kuhnigk et al., 1996; Cypionka, 2000). The activity is cyanidesensitive, which indicates that cytochromes might participate in electron transport to oxygen. Strain $\mathrm{TmAO}^{\mathrm{T}}$ also possesses high catalase activity, whereas it is superoxide dismutase-negative in both the xanthine/xanthine oxidase 
assay and the nitro blue tetrazolium salt reduction assay (Boga \& Brune, 2003).

Owing to its large capacity for hydrogen-dependent oxygen reduction and its exceptional tolerance to a temporary exposure to oxygen, strain $\mathrm{TmAO}^{\mathrm{T}}$ is able to initiate growth in non-reduced basal medium that contains up to $1.5 \mathrm{kPa}$ of oxygen in the headspace (Boga \& Brune, 2003). However, closer investigation revealed that growth commences only after the cells have rendered the medium anoxic and that reductive acetogenesis from $\mathrm{CO}_{2}$ is severely compromised if even traces of oxygen are present in the medium (Boga \& Brune, 2003).

It has been proposed that the ability of obligate anaerobes to scavenge oxygen, together with their apparent tolerance of toxic oxygen reduction products, would not only enable them to survive a temporary exposure to oxygen but would also allow them to actively re-establish favourable conditions for growth (Boga \& Brune, 2003). As the termite gut habitat is characterized by a large influx of oxygen via the epithelium (Brune, 1998; Brune et al., 2000), it is possible that strain $\mathrm{TmAO}^{\mathrm{T}}$ contributes to oxygen consumption within the micro-oxic periphery of the gut.

Based on phylogenetic, morphological and physiological differences, strain $\mathrm{TmAO}^{\mathrm{T}}$ is proposed as a novel member of the genus Sporomusa, with the name Sporomusa aerivorans sp. nov.

\section{Description of Sporomusa aerivorans sp. nov.}

Sporomusa aerivorans [ae.ri.vo'rans. L. n. aer air; L. pres. part. vorans digesting, devouring; N.L. pres. part. aerivorans devouring air (oxygen), referring to the high capacity of the organism to reduce oxygen].

Curved rods, $1 \cdot 3-7 \cdot 0 \mu \mathrm{m}$ long and $0 \cdot 6-0 \cdot 7 \mu \mathrm{m}$ wide. Motile by one or more lateral flagella. Stain Gram-positive but react Gram-negative in the $\mathrm{KOH}$ test. Catalase-positive but superoxide dismutase-negative. Terminal, heat-resistant endospores in club-shaped sporangia are formed. Oxygensensitive; does not grow in air. Resting cells reduce oxygen in the presence of hydrogen or by endogenous reductant; therefore, they can initiate growth in non-reduced medium under micro-oxic conditions. Chemo-organotrophic fermentative metabolism. Nitrate and sulfate are not used as external electron acceptors. Grows lithotrophically by reductive acetogenesis on $\mathrm{H}_{2}$ and $\mathrm{CO}_{2}$ in the presence of yeast extract or Casamino acids. Homoacetogenic; ferments L-lactate, pyruvate, citrate, L-alanine, D-mannitol, ethanol, formate and methanol to acetate as sole product. Fumarate, L-malate and oxaloacetate are fermented to propionate and acetate. Decarboxylates succinate and malonate to propionate or acetate, respectively. The $O$-methyl groups of syringate, vanillate and 3,4,5-trimethoxybenzoate are fermented to acetate. Does not grow on hexoses. Yeast extract or Casamino acids are required for growth and are fermented mainly to acetate. Possesses membrane-bound $b$-type cytochrome(s). Temperature range for growth is $19-35^{\circ} \mathrm{C}$, optimum $30^{\circ} \mathrm{C}$. No growth at 4 or $45^{\circ} \mathrm{C}$. $\mathrm{pH}$ range for growth is $6 \cdot 2-8 \cdot 2$, optimum $\mathrm{pH} 7$.

Type strain: $\operatorname{TmAO}^{\mathrm{T}}\left(=\mathrm{DSM} 13326^{\mathrm{T}}=\right.$ ATCC BAA- $\left.625^{\mathrm{T}}\right)$. Habitat: intestinal tract of the termite Thoracotermes macrothorax.

\section{Acknowledgements}

This study was supported by a research grant from the Deutsche Forschungsgemeinschaft (DFG). H. I. B. received a scholarship from Deutscher Akademischer Austauschdienst (DAAD). Edouard Miambi collected the termites and performed the serial dilutions from which the strains were isolated.

\section{References}

Blenden, D. C. \& Goldberg, H. S. (1965). Silver impregnation stain for Leptospira and flagella. J Bacteriol 89, 899-900.

Boga, H. I. \& Brune, A. (2003). Hydrogen-dependent oxygen reduction by homoacetogenic bacteria isolated from termite guts. Appl Environ Microbiol 69, 779-786.

Brauman, A., Kane, M. D., Labat, M. \& Breznak, J. A. (1992). Genesis of acetate and methane by gut bacteria of nutritionally diverse termites. Science 257, 1384-1387.

Breznak, J. (1994). Acetogenesis from carbon dioxide in termite guts. In Acetogenesis, pp. 303-330. Edited by H. L. Drake. New York: Chapman \& Hall.

Breznak, J. A. \& Blum, J. S. (1991). Mixotrophy in the termite gut acetogen, Sporomusa termitida. Arch Microbiol 156, 105-110.

Breznak, J. A. \& Switzer, J. M. (1986). Acetate synthesis from $\mathrm{H}_{2}$ plus $\mathrm{CO}_{2}$ by termite gut microbes. Appl Environ Microbiol 52, 623-630.

Breznak, J. A., Switzer, J. M. \& Seitz, H.-J. (1988). Sporomusa termitida sp. nov., an $\mathrm{H}_{2} / \mathrm{CO}_{2}$-utilizing acetogen isolated from termites. Arch Microbiol 150, 282-288.

Brune, A. (1998). Termite guts: the world's smallest bioreactors. Trends Biotechnol 16, 16-21.

Brune, A. \& Schink, B. (1990). A complete citric acid cycle in assimilatory metabolism of Pelobacter acidigallici, a strictly anaerobic, fermenting bacterium. Arch Microbiol 154, 394-399.

Brune, A., Frenzel, P. \& Cypionka, H. (2000). Life at the oxic-anoxic interface: microbial activities and adaptations. FEMS Microbiol Rev 24, 691-710.

Cypionka, H. (2000). Oxygen respiration by Desulfovibrio species. Annu Rev Microbiol 54, 827-848.

Dehning, I., Stieb, M. \& Schink, B. (1989). Sporomusa malonica sp. nov., a homoacetogenic bacterium growing by decarboxylation of malonate or succinate. Arch Microbiol 151, 421-426.

Dickerson, R. E. \& Timkovich, R. (1975). Cytochrome c. In The Enzymes, vol. XI, part A, pp. 397-547. Edited by P. D. Boyer. New York: Academic Press.

Diekert, G. (1992). The acetogenic bacteria. In The Prokaryotes, 2nd edn, pp. 517-529. Edited by A. Balows, H. G. Trüper, M. Dworkin, W. Harder \& K.-H. Schleifer. New York: Springer.

Diekert, G. \& Wohlfarth, G. (1994). Metabolism of homoacetogens. Antonie van Leeuwenhoek 66, 209-221.

Drake, H. L., Daniel, S. L., Matthies, C. \& Küsel, K. (1994). Acetogenesis: reality in the laboratory, uncertainty elsewhere. In 
Acetogenesis, pp. 273-302. Edited by H. L. Drake. New York: Chapman \& Hall.

Drake, H. L., Daniel, S. L., Küsel, K., Matthies, C., Kuhner, C. \& Braus-Stromeyer, S. (1997). Acetogenic bacteria: what are the in situ consequences of their diverse metabolic versatilities? Biofactors 6, 13-24.

Gregersen, T. (1978). Rapid method for distinction of Gramnegative from Gram-positive bacteria. Eur J Appl Microbiol Biotechnol 5, 123-127.

Hermann, M., Popoff, M.-R. \& Sebald, M. (1987). Sporomusa paucivorans sp. nov., a methylotrophic bacterium that forms acetic acid from hydrogen and carbon dioxide. Int J Syst Bacteriol 37, 93-101.

Ji, R., Kappler, A. \& Brune, A. (2000). Transformation and mineralization of synthetic ${ }^{14} \mathrm{C}$-labeled humic model compounds by soil-feeding termites. Soil Biol Biochem 32, $1281-1291$

Kambhampati, S. \& Eggleton, P. (2000). Taxonomy and phylogenetics of Isoptera. In Termites: Evolution, Sociality, Symbioses, Ecology, pp. 1-23. Edited by T. Abe, D. E. Bignell \& M. Higashi. Dordrecht: Kluwer.

Kamlage, B. \& Blaut, M. (1993). Isolation of a cytochrome-deficient mutant strain of Sporomusa sphaeroides not capable of oxidizing methyl groups. J Bacteriol 175, 3043-3050.

Kane, M. D. \& Breznak, J. A. (1991). Acetonema longum gen. nov. sp. nov., an $\mathrm{H}_{2} / \mathrm{CO}_{2}$ acetogenic bacterium from the termite, Pterotermes occidentis. Arch Microbiol 156, 91-98.

Kane, M. D., Brauman, A. \& Breznak, J. A. (1991). Clostridium mayombei sp. nov., an $\mathrm{H}_{2} / \mathrm{CO}_{2}$ acetogenic bacterium from the gut of the African soil-feeding termite, Cubitermes speciosus. Arch Microbiol 156, 99-104.

Karnholz, A., Küsel, K., Gößner, A., Schramm, A. \& Drake, H. L. (2002). Tolerance and metabolic response of acetogenic bacteria toward oxygen. Appl Environ Microbiol 68, 1005-1009.

Kuhner, C. H., Frank, C., Grießhammer, A., Schmittroth, M., Acker, G., Gößner, A. \& Drake, H. L. (1997). Sporomusa silvacetica sp. nov., an acetogenic bacterium isolated from aggregated forest soil. Int J Syst Bacteriol 47, 352-358.

Kuhnigk, T., Branke, J., Krekeler, D., Cypionka, H. \& König, H. (1996). A feasible role of sulfate-reducing bacteria in the termite gut. Syst Appl Microbiol 19, 139-149.

Küsel, K., Karnholz, A., Trinkwalter, T., Devereux, R., Acker, G. \& Drake, H. L. (2001). Physiological ecology of Clostridium glycolicum $\mathrm{RD}-1$, an aerotolerant acetogen isolated from sea grass roots. Appl Environ Microbiol 67, 4734-4741.

Leadbetter, J. R., Schmidt, T. M., Graber, J. R. \& Breznak, J. A. (1999). Acetogenesis from $\mathrm{H}_{2}$ plus $\mathrm{CO}_{2}$ by spirochetes from termite guts. Science 283, 686-689.
Ludwig, W. (1995). Sequence databases. In Molecular Microbial Ecology Manual, chapter 3.3.5, pp. 1-22. Edited by A. D. L. Akkermans, J. D. van Elsas \& F. J. de Bruijn. Dordrecht: Kluwer.

Ludwig, W. \& Strunk, O. (1996). ARB: a software environment for sequence data (http://www.arb-home.de).

Möller, B., Ossmer, R., Howard, B. H., Gottschalk, G. \& Hippe, H. (1984). Sporomusa, a new genus of Gram-negative anaerobic bacteria including Sporomusa sphaeroides spec. nov. and Sporomusa ovata spec. nov. Arch Microbiol 139, 388-396.

Ollivier, B., Cord-Ruwisch, R., Lombardo, A. \& Garcia, J.-L. (1985) Isolation and characterization of Sporomusa acidovorans sp. nov., a methylotrophic homoacetogenic bacterium. Arch Microbiol 142, 307-310.

Pfennig, N. \& Trüper, H. G. (1981). Isolation of members of the families Chromatiaceae and Chlorobiaceae. In The Prokaryotes, pp. 279-289. Edited by M. P. Starr, H. Stolp, H. G. Trüper, A. Balows \& H. G. Schlegel. Berlin: Springer.

Pfennig, N. \& Wagener, S. (1986). An improved method of preparing wet mounts for photomicrographs of microorganisms. J Microbiol Methods 4, 303-306.

Rosencrantz, D., Rainey, F. A. \& Janssen, P. H. (1999). Culturable populations of Sporomusa spp. and Desulfovibrio spp. in the anoxic bulk soil of flooded rice microcosms. Appl Environ Microbiol 65, 3526-3533.

Schink, B. (1994). Diversity, ecology, and isolation of acetogenic bacteria. In Acetogenesis, pp. 197-235. Edited by H. L. Drake. New York: Chapman \& Hall.

Schink, B. (1997). Energetics of syntrophic cooperation in methanogenic degradation. Microbiol Mol Biol Rev 61, 262-280.

Schmitt-Wagner, D. \& Brune, A. (1999). Hydrogen profiles and localization of methanogenic activities in the highly compartmentalized hindgut of soil-feeding higher termites (Cubitermes spp.). Appl Environ Microbiol 65, 4490-4496.

Springer, N., Ludwig, W., Drozanski, W., Amann, R. \& Schleifer, K.-H. (1992). The phylogenetic status of Sarcobium lyticum, an obligate intracellular bacterial parasite of small amoebae. FEMS Microbiol Lett 96, 199-202.

Tholen, A. \& Brune, A. (1999). Localization and in situ activities of homoacetogenic bacteria in the highly compartmentalized hindgut of soil-feeding higher termites (Cubitermes spp.). Appl Environ Microbiol 65, 4497-4505.

Tholen, A., Schink, B. \& Brune, A. (1997). The gut microflora of Reticulitermes flavipes, its relation to oxygen, and evidence for oxygen-dependent acetogenesis by the most abundant Enterococcus sp. FEMS Microbiol Ecol 24, 137-149.

Willems, A. \& Collins, M. D. (1995). Phylogenetic placement of Dialister pneumosintes (formerly Bacteroides pneumosintes) within the Sporomusa subbranch of the Clostridium subphylum of the grampositive bacteria. Int J Syst Bacteriol 45, 403-405. 